\title{
Бульозний пемфігоїд Левера у хворого на метастатичний рак легені після лікування атезолізумабом
}

\author{
Медичий інститут Сумського державного університету, Суми \\ Одержано 21.12.2018 \\ Прийнято до друку 24.01.2019 \\ DOI: $10.32471 /$ clinicaloncology.2663-466X.38.22146
}

\begin{abstract}
Наведено клінічний випадок розвитку бульозного пемфігоїду Левера у хворого на метастатичний рак легені після лікування атезолізумабом. Мета. Розглянути основні механізми розвитку аутоімунного ураження шкіри та особливості лікування при цьому захворюванні. Об'єкт і методи. Аналіз даних зарубіжної наукової літератури стосовно механізму розвитку бульозного пемфігоїду Левера. Опис клінічного спостереження. Використано науково-дослідницький, аналітичний та узагальнюючий методи дослідження. Результати. Бульозний пемфігоїд може розвиватися внаслідок впливу на імунологічні контрольні точки, що призводить до порушення балансу між імунною толерантністю та реактивністю. Висновки. Бульозний пемфігоїд Левера у цього пацієнта - це рідкісний прояв аутоімунного ураження шкіри внаслідок прийому PD-L блокатора атезолізумабу. Прогноз для пацієнтів $€$ несприятливим.
\end{abstract}

Ключові слова: бульозний пемфігоїд; атезолізумаб; лікування; PD-L рецептори.

Бульозний пемфігоїд Левера - один із найрідкісніших проявів аутоімунного ураження шкіри. Виникає з частотою 0,2-0,5 випадку на 1000000 населення [1]. Хвороба уражує пацієнтів усіх вікових груп, але переважно - категорію осіб старше 50 років [2]. У науковій літературі описано випадки розвитку бульозного пемфігоїду після прийому фуросеміду, ібупрофену, каптоприлу, спіронолактону, метронідазолу, пеніциліну, ампіциліну, левофлоксацину та деяких інших препаратів, однак існують лише поодинокі повідомлення щодо виникнення цього ускладнення у пацієнтів на фоні імунотерапії злоякісних новоутворень. PD-L блокатори (блокатори рецепторів програмованої загибелі клітин) докорінно змінили сценарій перебігу раку, хоча і зумовили при цьому можливість розвитку такого небезпечного небажаного явища, як пемфігоїд Левера.

Пемфігус для характеристики будь-якого висипу з пухирями вперше описав G.T. Elliott ще у 1895 р. На прикладі двох пацієнтів він зобразив клінічну картину, яка найбільш точно відображала перебіг цього захворювання «без ураження інших членів родини» [3]. У це поняття вкладалася поява пухирів різної етіології. І лише у 1953 р. Волтер Левер на підставі специфічних клінічних та гістологічних ознак відокремив бульозний пемфігоїд від інших пемфігусів.

Наразі доведеною є аутоімунна етіологія виникнення цього захворювання. Доказом цього є розвиток клітинної та гуморальної відповіді, спрямованої проти колагену VII типу (трансмембранного білка, який ще називають БП180, БПАГ2) та антигену БП230 (цитоплазматичного білка сімейства плакінів, або БПАГ1). Функцією зазначених антигенів, які є компонентами напівдесмосом, є підтримання стромально-епітеліального з'єднання. У пацієнтів із бульозним пемфігоїдом з'являються аутоантитіла до базальної мембрани зовнішнього шару шкіри - епідермісу. Про їхню комплементзв'язувальну активність свідчить специфічне світіння базальної мембрани в реакції імунофлюоресценції. Як наслідок описаних процесів, відмічається специфічне відшарування епідермісу. Аутоімунну теорію виникнення бульозного пемфігоїду Левера також підтверджує його зв'язок із гаплотипами другого класу головного комплексу гістосумісності та гарною відповіддю на імуносупресивну терапію [2].

Ще однією причиною розвитку аутореактивності може бути вплив на імунологічні контрольні точки, що є регулятора- ми імунної системи. Ці шляхи мають вирішальне значення для несприйнятливості імунної системи до речовин або тканин, які мають здатність викликати імунну відповідь у організму, що не дозволяє імунній системі не розбираючи нападати на власні клітини. Молекули інгібіторної контрольної точки $€$ мішенями при імунотерапії раку. Наразі схвалені інгібітори контрольних точок блокують CTLA-4, PD-1 і PD-L1. За відповідні фундаментальні наукові відкриття Джеймс П. Еллісон і Тасуку Хонджо у 2018 р. отримали Нобелівську премію з фізіології та медицини [4].

Баланс між імунною толерантністю та імунною реактивністю підтримується завдяки Т-лімфоцитам. Для їх активації потрібен як антиген, так і інший сигнал, який відправляється через такі молекули, як CD28. При зв'язуванні з молекулами В7, такими як CD80 (B7-1) або CD86 (B7-2), корецептори CD28 на Т-клітинах забезпечують позитивний стимуляторний сигнал. Водночас молекули CTLA-4 забезпечують негативний інгібуючий сигнал. PD-1, як і CTLA-4, належить до сімейства CD28 і продукує негативний сигнал при взаємодії з його лігандами, PD-L1 (B7-H1 або CD274) i PD-L2 (B7-DC або CD273), які належать до сімейства B7 [5].

Іншими етіологічними факторами розвитку аутоімунного ураження є високий рівень експресії CTLA-4 та PD-1 на регуляторних $\mathrm{CD} 4^{+} \mathrm{CD} 25^{+} \mathrm{T}$-лімфоцитах. Саме вони беруть участь у підтримці механізмів периферичної імунної толерантності. Активація цих рецепторів запобігає зриву імунної толерантності до власних клітин організму шляхом стимуляції проліферації регуляторних Т-клітин. Особливістю багатьох пухлин $є$ те, що вони інфільтровані регуляторними Т-лімфоцитами. Блокада їх активності за допомогою атезолізумабу сприяє посиленню протипухлинної імунної відповіді шляхом усунення імуносупресії, що є наслідком впливу регуляторних Т-лімфоцитів. 3 іншого боку, надмірне пригнічення цих клітин призводить до зриву імунної толерантності та розвитку аутоімунних процесів, зокрема і в шкірі [6].

У статті представлене клінічне спостереження розвитку бульозного пемфігоїду після тривалого прийому PD-L блокатора атезолізумабу.

\section{КЛІНІЧНЕ СПОСТЕРЕЖЕННЯ}

Пацієнт K., 62 років, отримував лікування в Сумському онкологічному диспансері з приводу злоякісного новоутво- 

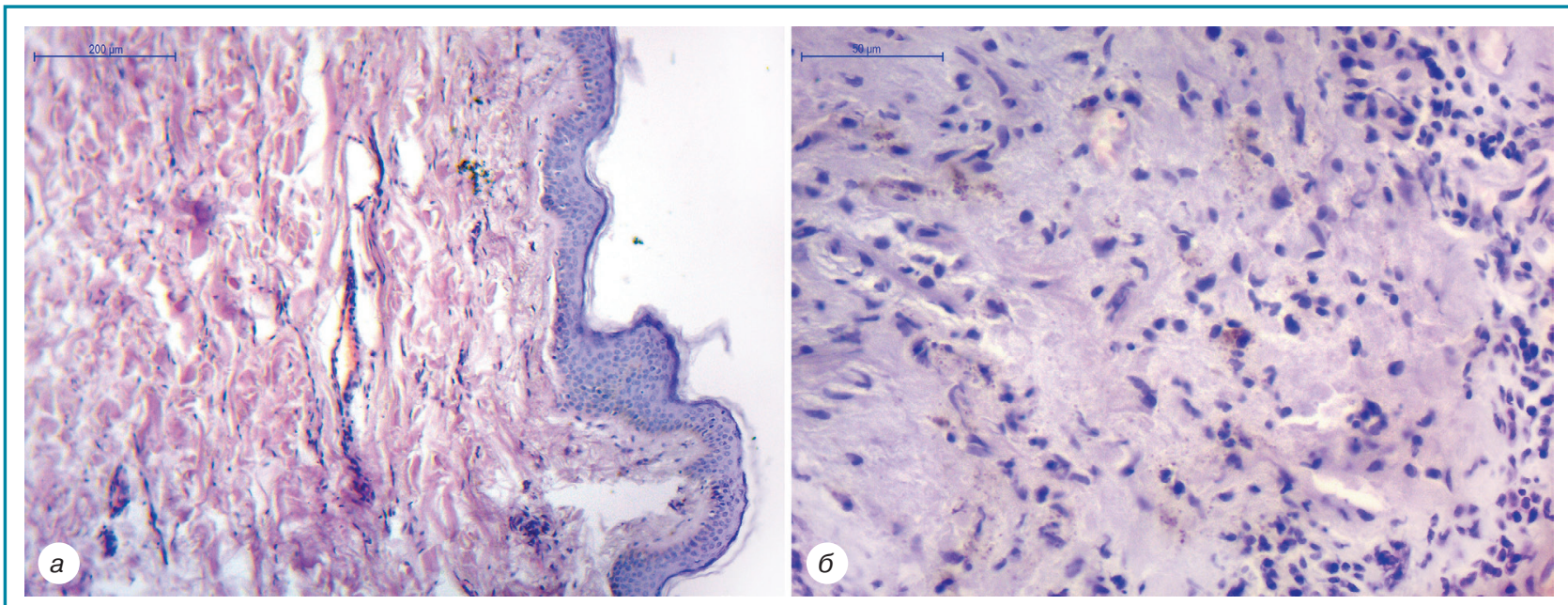

Рис. 1. Бульозний пемфігоїд: $а$ - набряк, пухир, що формується; забарвлення гематоксиліном та еозином, зб. × 100; б запальний інфільтрат з нейтрофілами та поодинокими еозинофілами; забарвлення гематоксиліном та еозином, зб. $\times 400$

рення верхньої частки правої легені. Від самого початку була встановлена IV стадія захворювання. На момент виникнення бульозного пемфігоїду хвороба вже 24 міс вдало піддавалася лікуванню. За увесь період спостереження пацієнт отримав 6 курсів хіміотерапії за схемою: паклітаксел 100 мг/м² + карбоплатин (AUC 6) + атезолізумаб 1200 мг внутрішньовенно краплинно кожні 3 тиж. Оскільки була зареєстрована часткова відповідь на лікування та відсутність прогресування захворювання, пацієнт перейшов у режим монотерапії препаратом атезолізумаб у дозі 1200 мг внутрішньовенно краплинно кожні 3 тиж.

Небажане явище у вигляді бульозного пемфігоїду Левера виникло після 33-го введення PD-L блокатора. На 20-й день після інфузії препарату хворий поскаржився на появу двох еритематозних плям у лівій надключичній ділянці та однієї плями у міжпальцевому проміжку на правій кисті. Плями були розміром приблизно $2 \times 1,5$ см, яскраворожевого кольору, відзначався незначний свербіж. Явище було трактовано як алергія, а пацієнту призначено гідрокортизонову мазь та препарат левоцетиризину у дозуванні 5 мг на добу. На 21-й день проведено планову інфузію препарату атезолізумабу (34-й цикл). На 4-й день після введення у пацієнта з'явилися нові множинні еритематозні плями у правій та лівій надключичних ділянках, міжпальцевих проміжках обох рук, паховій ділянці, на статевих органах та нижній частині живота. Частина утворень мали вигляд щільних та напружених напівсфер за рахунок відшарування епідермісу. На 5-й день ці пухирі почали лопатися з виділенням серозного вмісту світло-жовтого кольору. На їх місці залишалася свіжа еродована поверхня. У міру підсихання серозного вмісту з'являлися жовті кірочки. Загальний стан пацієнта був задовільний. У клінічному та біохімічному аналізі крові не відмічалося жодних клінічно значимих відхилень, еозинофілія відсутня. 3 діагностичною метою проведена біопсія одного з пухирів для гістологічного дослідження (рис. 1).

Тканина біоптату шкіри мала ознаки помірного набряку дерми, виявлялися навколосудинні запальні інфільтрати. Помітний початок формування пухиря у вигляді порожнини під епідермісом, який починає відшаровуватися. До складу запальних інфільтратів у дермі, навколо судин та пухирів входять нейтрофіли та еозинофіли. Акантоліз відсутній.

Ретроспективно оцінено, що у пацієнта наявне набажане явище - бульозний пемфігоїд Левера. Хворому терміново призначено преднізолон у дозі 0,5 мг/кг на добу перорально. Плями та пухирі продовжували обробляти гідрокортизоновою маззю, а свіжі ерозії - хлорамфеніколом і метилурацилом з метою профілактики вторинного інфікування.
Уже за 7 днів імуносупресивного лікування стан пацієнта значно покращився: частина еритематозних плям так і не перетворилася на пухирі, ерозії швидко епітелізувалися, залишаючи на своєму місці темні пігментовані ділянки. Дозу преднізолону почали поступово знижувати зі швидкістю 5 мг на тиждень. Динаміку розвитку змін шкіри зображено на рис. 2.

Після зниження дози до 10 мг у пацієнта трапився рецидив бульозного пемфігоїду. Пухирі з'являлися у місцях попередньої локалізації. Доза преднізолону була повторно підвищена до 40 мг на добу. Протягом 1 тиж прийому препарату позитивної динаміки не спостерігалося, тому вогнища додатково зовнішньо обробляли маззю клобетазолу. Після 3 тиж боротьби 3 рецидивом захворювання неепітелізованими залишалися лише 3 вогнища у паховій ділянці, і дозу преднізолону знову почали поступово знижувати.

Пацієнт помер. Причиною смерті стала масивна легенева кровотеча.

Отже, бульозний пемфігоїд Левера у цього пацієнта це рідкісний прояв аутоімунного ураження шкіри внаслідок прийому PD-L блокатора атезолізумабу. Цей стан потребує повної відміни прийому препарату. Хвороба лише на перший погляд вдало піддається імуносупресивній терапії. При досягненні пацієнтом підтримувальної дози преднізолону (10 мг) відмічається рецидив бульозного пемфігоїду Левера, який дуже важко контролювати. Тривалий прийом

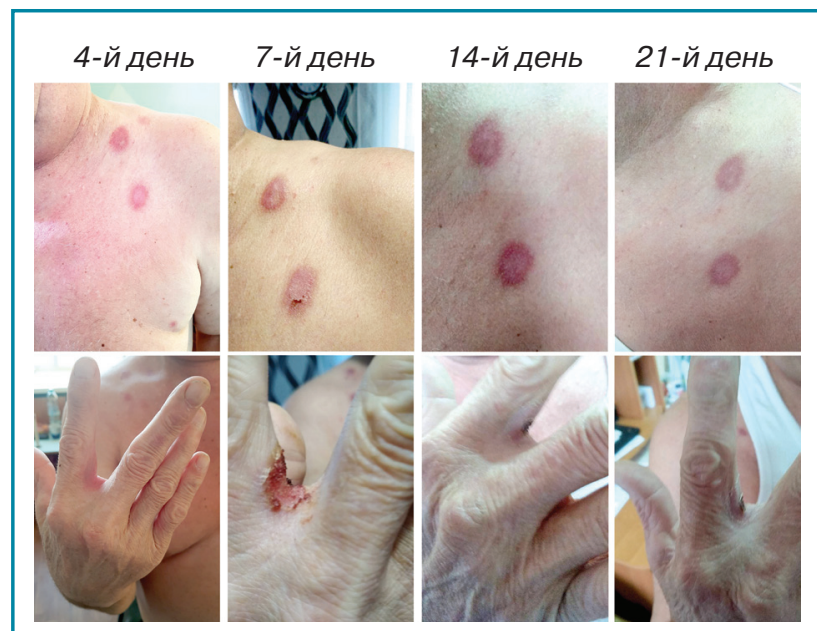

Рис. 2. Динамікарозвиткупухирів на 4-й, 7-й, 14-йта21-йдень захворювання 
стероїдних гормонів зумовлює ризик розвитку ускладнень, що загрожують життю.

\section{СПИСОК ВИКОРИСТАНОЇ ЛІТЕРАТУРИ}

1. Wong S.N., Chua S.H. (2002) Spectrum of subepidermal immunobullous disorders seen at the National Skin Centre. Singapore: a 2-year review. Br. J. Dermatol. 147(3): 476-480. doi:10.1046/j. 1365-2133.2002.04919.

2. Vorobyev A., Ludwig R.J., Schmidt E. (2017) Clinical features and diagnosis of epidermolysis bullosa acquisita. Exp. Rev. Clin. Immunol., 13(2): 157-169. doi 10.1080/1744666X.2016.1221343.

3. Elliott G.I. (1895) Two cases of epidermolysis bullosa. J. Cutan. Genitourin. Dis., 13: 10

4. The Guardian (2018) James P Allison and Tasuku Honjo win Nobel prize for medicine. Retrieved from https://www.theguardian.com/science/2018/oct/01/ jamesp-allison-and-tasuku-honjo-win-nobel-prize-for-medicine.

5. Iwai Y., Hamanishi J., Chamoto K., Honjo T. (2017) Cancer immunotherapies targeting the PD-1 signaling pathway. J. Biomed. Sci., 24(26): 2-11. doi 10.1186/s12929-017-0329-9.

6. Bolognia J.L., Jorizzo J.L., Schaffer J.V. (2012) Dermatology: 2-volume set. 3-rd ed. Saunders, $3776 \mathrm{p}$.

\section{Буллезный пемфигоид Левера у больного метастатическим раком легкого после лечения атезолизумабом}

И.А. Винниченко, Ю.В. Москаленко, О.И. Винниченко, Р.А. Москаленко, А.М. Поддубный Медицинский институт Сумского государственного университета, Сумы

Резюме. Представлен клинический случай развития буллезного пемфигоида Левера у больного метастатическим раком легкого после лечения атезолизумабом. Цель. Рассмотреть основные механизмы развития аутоиммунного поражения кожи и особенности лечения этого заболевания. Объект и методы. Анализ данных зарубежной научной литературы относительно механизмов развития буллезного пемфигоида Левера. Описание клинического наблюдения. Использованы научно-исследовательский, аналитический и обобщающий методы исследования. Результаты. Буллезный пемфигоид может развиваться вследствие воздействия на иммунологические контрольные точки, что приводит к нарушению баланса между иммунной толерантностью и реактивностью. Выводы. Буллезный пемфигоид Левера уданного пациента - это редкое проявление аутоиммунного по- ражения кожи вследствие приема PD-L блокатора атезолизумаба. Прогноз для пациента является неблагоприятным.

Ключевые слова: буллезный пемфигоид; атезолизумаб; лечение; PD-L рецепторы.

Lever's bullous pemphigoid in a patient with metastatic lung cancer after treatment with atezolizumab

I.O. Vynnychenko, Y.V. Moskalenko, O.I. Vynnychenko, R.A. Moskalenko, A.M. Piddubny Medical Institute of Sumy State University, Sumy

Summary. The clinical symptoms of Lever bullous pemphigoid in patient with metastatic lung cancer after treatment with atezolizumab are described. The aim. To consider the main mechanisms of development of autoimmune skin lesions and features of treatment of this disease. Materials and methods. Analysis of the data of international scientific literature concerning the mechanism of development of Lever's bullous pemphigoid was done. Case report was described. Analytical and generalizing research methods were used. Results. Bullous pemphigoid may develop as a result of receiving checkpoint inhibitors, which leads to imbalance between immune tolerance and reactivity. Conclusions. Lever's bullous pemphigoid is a rare skin condition that occurs after administration of atezolizumab. The prognosis for the patients is unfavorable.

Key words: bullous pemphigoid; atezolizumab; treatment; PD-L receptors.

Адреса:

Москаленко Юлія Василівно

40000, Суми, вул. Римського-Корсакова, 2

Сумський державний університет

E-mail:yl.moskalenko@med.sumdu.edu.ua 